\title{
The Impact of the Social Networking Sites on the Research Activity of University Students
}

\author{
Asif Mahmood ${ }^{1}$, Farhan Ahmed Khan ${ }^{1}$
}

\begin{abstract}
Despite the widespread utilization of online networking by students and its expanded use by teachers, almost no experimental proof is accessible concerning the effect of social networking use on learner, learning and engagement. This paper investigates the impact of social Networking Sites on the research activity of university students. The sample is composed of 200 students from the PU, Lahore and UET, Lahore, out of which 87 male (43.5\%) and 113 females $(56.5 \%)$ responded the questionnaire of survey. The finding reveals that Facebook was utilized for different sorts of scholastic and co-curricular talks. The ANOVA results demonstrated that the trial gathering had an altogether more noteworthy expand in engagement than the control bunch, and additionally higher semester evaluation point midpoints. This research also demonstrates that the motivation behind joining a social networking site differs among the students, however, the reason for being is to stay connected with the group to further impart learning to others. Presentation to late information, abilities and innovation in their general vicinity of specialization started things out.
\end{abstract}

Keywords: Social Network Sites, University, Research Activity, ANOVA

\section{Introduction}

As of late, the long range informal communication site has turned into a standout amongst the most imperative correspondence implies. Regardless individual to individual correspondence exist looking into a definitive concentration to give correspondence among people paying little regard to the package, making it open to people sensibly give data, records, pictures and parts, make area and send messages, and lead solid talks. These structures are appeared as social, in a general sense in light of the way that they allow correspondence with amigos, understudies and associates so adequately and potentially. It looks like way props the ties between people of those structures. In the space of web district the most revered are Facebook, Twitter and others. These domains and gatherings are framework for correspondence particularly with different people socially and in media. They are having tremendous and prompting influence essential master in the occasions from the general world fiscally, politically, socially and instructively.

${ }^{1}$ Institute of Business \& Management (IB\& M), University of Engineering and Technology, Lahore Pakistan 
The driving parts for get-together of Social Networking site are the consistently far reaching find the opportunity to, solace, settlement, and flexibility of social advances (Brown, S. 2010; Schroeder, A., Minocha, S., \& Schneider, C, 2010). It has been combat that poor more recognizable prepare, social movements helps social constructivist structures with learning they maybe need to improve understudies' change of appreciation and push learner joint effort (Ferdig, R. E, 2007; Schroeder, A., Minocha, S., \& Schneider, C, 2010; McLoughlin, C., \& Lee, J. W. L, 2008). An additional preferred standpoint of social advances gave on the web is that they are once in a while free or require immaterial financing, taking out a potential impediment to get-together (Brown, S. 2010).

There are diverse outline and suppositions which saw four honest to goodness slants of Social Networking site use in higher course. These combine, refreshing relationship, overhauling learning inspiration, offering revamp course material, and making bunch limits ( Wheeler, S., Yeomans, P., \& Wheeler, D, 2008; Rifkin, W., Longnecker, N., Leach, J., Davis, L., \& Ortia, L, 2009). This surmises long range easygoing correspondence rehearses have the likelihood of improving learner contact and is utilized to update their cooperation in class, especially where contemplating learners are consolidated. Understudies can work in electronic gathering learning, with less or no uneasiness of planning to raise issues before accomplices at school (Wheeler, S., Yeomans, P., \& Wheeler, D, 2008).

\section{Literature Review}

Earlier reviews, for instance, (Kennedy, G., Dalgarno, B., Bennet, S., Gray, K., Waycott, J., Judd, T., et al., 2009), examined the general accommodation of Social frameworks organization site among understudies in various Colleges and Universities. Basically (Hemmi, A., Bayne, S., \& Land, R, 2009; Jones, M. C., \& Twidale, M. B, 2005), examined the use of long range relational correspondence and keep up that, the designation of social advances is not a straightforward and clear process. At more hoisted measure of preparing all the more baffling academic assignments are dealt with and the new time of understudies apparently comprehends that Social frameworks organization site and social advances are convincing to learning.

Different earlier reviews have demonstrated verification that attempts are required with a particular ultimate objective to start using Social Networking site inside demand to affect educational activities. In any case, the whole strategy of accepting a particular Social Networking site has not gotten tasteful thought from authorities (Hamid, S., Waycott, J., Chang, S. \& Kurnia, S, 2011). Researchers have battled that in showing up and taking in the blend of media to engage the procedure is generally affected particularly in relationship with enhancing last postponed results of researchers (McLoughlin, C., \& Lee, J. W. L, 2008; Tay, E., \& Allen, M, 2012). As per (Tay, E., \& Allen, M, 2012), understudies should be given vigilant examinations to check their

Sukkur IBA Journal of Management and Business - SIJMB | Volume 5 No. 2 July - December 2018 @ Sukkur IBA University 
use of the instruments they feel calm and familiar with which they feel are utilitarian in fulfilling scholarly attempts. Regarding, the social affordances of using long range social correspondence may not be given in a solitary specific social building however rather inside the mix of two or three social progressions.

Past creating saw the inconveniences that are joined with utilizing Social Networking site as a bit of higher bearing. The survey included 100 people for the reviews from Punjab University and UET, Lahore each. The audit found that, there are 4 significant inconveniences of long range social correspondence and its relationship with modifying, for example, thinking about advancement and copyright issues slant data ask. Teachers every so often are not jump forward and couldn't see how to mastermind and abuse social programming in their classes. The divulgences of the survey affirmed the before issues sketched out by (Kennedy,Judd, Churchward, Gray, \& Krause, 2008). (Kennedy, Judd, Churchward, Gray, \& Krause, 2008), as exhibited by their cutting edge inspect in three Australian Universities. As shown by (Kennedy, Judd, Churchward, Gray, \& Krause, 2008), demonstrated six issues fusing instructional technique with respect to progression mix. Despite the advantages and difficulties saw, the survey also uncovered that teachers that don't have a place with the new time are suspicious to easygoing affiliation coordination in class. Educators are impacted to be careful in their circulation and utilization of long range easygoing correspondence as to concentrate on the varying learners' learning incline. Also, the researchers ought to pick we have the progression that meets their calling. The class encounter can't be satisfied their seeing, however in like way they ought to moreover use the seeing inside basic vicinity of working. The likelihood of taking a gander at understanding and satisfying changing through the accommodating correspondence like Facebook, Talking, E-mail and Website or any sorts of learning stakes that let the understudies in thankfulness and experience analyzing between your learners, coach, specialists, experts or even the business proprietor can help the analysts in getting the lesson learned towards the relationship in unmistakable closeness of working. The centrality of individuals all reasons pointed out, the master has motivation to make a discovered skeleton of Social systems administration to help Collaborative Learning (SSCL) for updating understanding change (Yampinij et al., 2012).

\section{Social Networking Site for Academic Purpose}

Using Social frameworks organization site by University students is certainly an entrancing task of examination for educationists and social investigators. Hamid, S. Chang, S. \& Kurnia, S. 2009), Maintain that in the accessible composed work there are helpful plans and styles of utilizing it at school level. It outlines the presentation of substance and concentrates on the most capable strategy to give, work together, and collaborate and systematize by its use. There have every one of the reserves of being particular top motivations to benefactor using Social structures association site as a touch of more basic run the show. Its use was insisted by extra setup. Its all right with invigorate consider experiences of learners by acquisition of e-help benefits for their

Sukkur IBA Journal of Management and Business - SIJMB | Volume 5 No. 2 July - December 2018 @ Sukkur IBA University 
breathing space (Dabner, N, 2011). It thinks about engage correspondence among and between students in virtual urban districts. Among others, the Facebook shows up being more than likely the most respected was proposed as a procedure for correspondence for landing at learners (Mack, D., Behler, A., Roberts, B., \& Rimland. E, 2007).

Web locales focus seriously on building online metropolitan domains beyond any doubt to close by fundamental side interests or activities. Accordingly oblige them contraptions that help them to move this. Inside the bit of total taking in, the web ranges managed the immense issue lifted by educators inside the late period. For instance, lacks in philanthropic perspective and saw to it showing needs soul. Regardless, Websites have bolstered to loosen up individuals' issues, with the help of regular part by getting an individual, making the excitement inside the human consider the scholastic method something key. That comfortable with a develop with pull in individuals to bunch masterminded learning and different specialists inside the parts of humanistic systems undertaking studies to take a gander at this sensation and to clarify the honest to goodness explanation behind the premium educated about web goals for event (Ractham, P.; Firpo, D, 2011; Hao Jiang; MingXi Tang, 2010). What's more, teachers have definite that utilizing on the web improvements can support online talk among learners outside the classes, past the customary class setting (Gray, K., Chang, S., \& Kennedy, G, 2010). Inside the states of web objectives or web journals, when understudies upgrade their client profiles and re-try their novel pages, they could give expansive particulars about themselves (e.g., full title, date of origination, area, informative establishment, and relaxation activities).The scholastics that are utilizing such advances inside their class will have an approach to manage uncover liberally all the more about the understudies they arrange essentially by overview the learners' profiles (Griffith, S., \& Liyanage, L, 2008).

\subsection{Effects of Social Networking Site on The Research Activity Of Students of University}

The Social Networking site charms students and ought to be audited as business visionaries of appreciation. The medium of web is publicizing with extension in its activities. The watchful character of online conditions has connected with individual to individual correspondence. Catching through individual to individual correspondence begun just like a forte development, however time it's a wonder. The areas are utilized from different viewpoints like making metropolitan ranges, talking, and blogging and so on. Additionally contrasting foundations even these days are making get-togethers on two or three Websites (Saba Mehmood, 2013).

The improved utilization of Websites has changed into a general sensation for quite a while. What began basically like a side energy for a couple machine showed people has changed over to a social standard and closeness style for individuals from around the world (Nicole Ellison, 2007). Youngsters and teenagers have especially watched these web destinations to have the capacity to contact their amigos, offer information, go over their personas, and highlight their social lives (Nicole Ellison, 2007).

Sukkur IBA Journal of Management and Business - SIJMB | Volume 5 No. 2 July - December 2018 @ Sukkur IBA University 
While using the work of movement reliable to get together with others near to the acknowledgment on the web, Internet objectives are at this moment being an improvement that is finished fundamentally on the web, with Websites (Vaughn, Coyle, 2008).

As appeared by (Khan U 2009), Facebook clients once in a while time experience poor execution scholastically. Fundamentally, (Englander, Terregrossa and Wang, 2010), put that Social systems association site is unfairly connected with adroit execution of learner and is a ton a more vital number of eminent than its focal core interests. Web inclination along these lines gave move in web use inside the latest couple of decades (Nalwa K, Anand AP, 2003). Suggested that penniless clients lean toward utilizing web setting back their particular and ace duties which at long last prompts poor scholastic execution.

As demonstrated by (Karpinski A, 2009), pointed out that Facebook customers gave lesser time to their reviews in relationship with nonusers did and along these lines had chopped down GPAs. (Karpinski, A, \& Duberstein, 2009), Also said that among various novel redirections of every last time, Facebook remains an essential diversion of current time. As demonstrated by (Kubey, Lavin, and Barrows, 2001), incapacitating of informative execution and web dependence are connected by utilizing synchronous correspondence meanders including web regions and trades. There are points of interest and risks related to using any nice get-together. There have been reports as to its effect on understudies' academic execution. A few experts gotten some information about the completed consequence of accommodating correspondence settlement among University learners' and with their insightful execution.

They found a poor effect and effect when the media is abuse in such a course, to the point that don't informatively upgrade learning or its procedure (Wang, Chen \& Liang, 2011; Stollak, Vandenberg, Burklund, \& Weiss, 2011; Rouis, Limayem, \& SalehiSangari, 2011; Canales, Wilbanks \& Yeoman, 2009). Other specialists surveyed this same issue however discovered either no critical association between utilizing individual to individual correspondence and understudy clever execution (Ahmed \& Qazi , 2011; Hargittai, \& Hsieh, 2010), or truly a part in students' scholastic execution (Pasek \& Hargittai, 2009).

\section{Methodology}

\subsection{Research Design \& Sampling}

This study used the quantitative approach to manage find the acknowledgment and assessments of the web based systems administration sorting out, among the understudies of Punjab University UET, Lahore. The information for this review was accumulated by method for a survey questionnaire on 100 M.Phil and Ph.D researchers in the UET, Lahore and 100 surveys in Punjab University Lahore in the midst of the present scholastic session. The irregular examining method was utilized for the accumulation of information. The age-extent of the respondents was between 18 to $>50$. The understudies were advised in the study to offer information about their encounters

Sukkur IBA Journal of Management and Business - SIJMB | Volume 5 No. 2 July - December 2018 @ Sukkur IBA University 
and effect of utilizing Social networking site on research action through collaborative learning.

\subsection{Respondents}

In this exploration 100 arrangements of questionnaires were haphazardly dispersed to M.Phil/MS and Ph.D. understudies of the University of the Punjab and 100 surveys in UET, LAHORE. SPSS programming (Version-16) application was utilized to investigate the information. The instrument utilized for this review was composed, in view of the targets of the utility and impacts of Social networking sites (SNS) on the exploration movement of the understudies of Punjab University (PU) and UET, Lahore. That was worthy and the instrument had met the dependability prerequisite for the review.

\subsection{Data Collection Procedure}

The Five-point Likert Scale was utilized as a part of this review. The review was calibrated with reference to a pilot contemplate done with understudies, and tried before-hand, analyzes the understudies' sentiments about the utilization of Social networking site on research execution. A survey containing 35 things was laid out. Each part was given a review and a short establishment to the review. The things were balanced from set up survey (Dr. Thiyam Satyabati Devi \& Ms. Sipiwe Tevera University of Swaziland, 2014).

\subsection{Conceptual framework}

This review explanation behind a concise discourse on the substance in the recommended system for the Impact of SNS use on research yield of PU and UET, Lahore students. Regardless, in any case, this examination finds that Social systems administration site mix identifies with the understudies' exploration execution, the elements seen to be used of Social systems administration site, in this audit are: Similarly, an applied structure that perceives instruments by which using Social systems administration site impacts analyze look into exercises of understudies of college, through different uses and reasons are given (see Fig. 3.1).It is prescribed that understudy mind from the relationship easily of use that get from utilizing of Social networking site propel dynamic community oriented learning and, which at long last achieves updated utility of research understudies of University. Association is made like a fundamental edge in the planning strategy. It urges understudies to have a remarkable time playing the class dynamic synergistic learning (So, \& Brush, 2008). The nearness of these parts is instrumental in improving collective learning and students' scholastic performance.

Sukkur IBA Journal of Management and Business - SIJMB | Volume 5 No. 2 July - December 2018 @ Sukkur IBA University 
Following Hypothesis is based on Conceptual Framework:

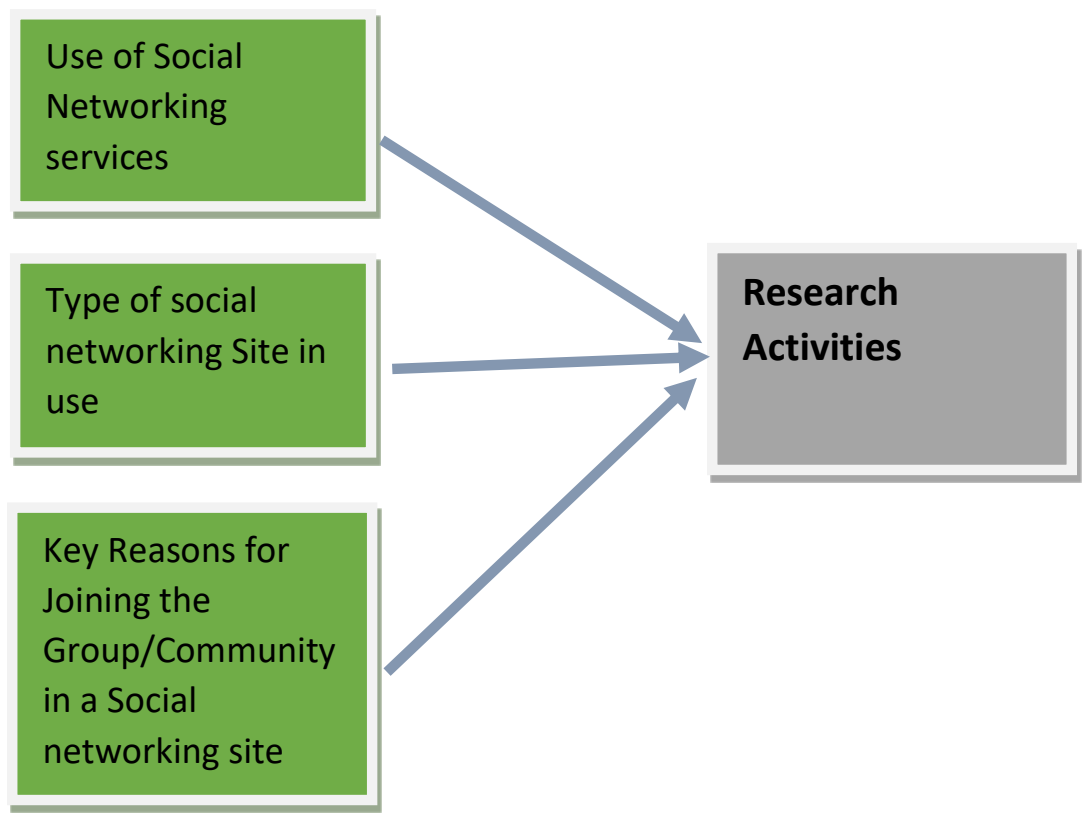

Figure 1 Conceptual Framework

H1: Use of social networking services is positively associated with the utility of research students of university

H2: Types of social networking site are positively associated with the effectiveness of research students of university

H3: Key Reasons for Joining the Group/Community in a Social networking site is positively associated with the utility of research activity students of university

\section{Results}

To analyze the data for this study, the Multiple Linear regression models were utilized as statistical tools. This model was used to analyze impacts of three independent variables towards the dependent variable. The examination with Multiple Linear regression helps in seeing the amount of the change in the Criterion variable is clarified by an arrangement of indicators (independent variables). The model is more fitting to be utilized since it can also explain the correlation between the dependent and independent variables in a bit better way. The accompanying outcomes were found from the information which exhibited comes about cleared up underneath. The Analysis of

Sukkur IBA Journal of Management and Business - SIJMB | Volume 5 No. 2 July - December 2018 @ Sukkur IBA University 
things helps us evaluate the connection of related review things with just a couple of measurements. Most basic is Cronbach's alpha, a singular number that tells you how well a course of action of things measures a single trademark. This estimation is a general thing relationship where the qualities extend in the vicinity of 0 and 1 . Values over 0.7 are every now and again thought to be agreeable.

To perceive the hazardous things, take a gander at the Omitted Item Statistics area of the yield. This range let us know how removing any one thing from the investigation upgrades or decreases Cronbach's alpha. This information grants us to tweak our overview, keeping the colossal request while supplanting the awful.

Table 1: Reliability Statistics

\begin{tabular}{ll}
\hline Cronbach's Alpha & Number of Items \\
\hline 0.873 & 32 \\
\hline
\end{tabular}

The value of Cranach's Alpha in this study is 0.873 which is acceptable and shows the reliability of survey.

Table 2: Variables Entered/Removed

\begin{tabular}{|c|c|c|c|}
\hline Model & Variables Entered & Variables Removed & Method \\
\hline
\end{tabular}

a. All requested variables entered.

R-square shows there is $53 \%$ change in dependent variable due to variation in independent variables whereas the remaining $73.0 \%$ change in D.V are due to other variables, in the model. $\mathrm{R}$ shows that variables have strong correlation with each other as its value is above $50 \%$. Which is a good indicator by now, but research activity of students have a great impact due to predictor in both situations.

Table 3: ANOVA

\begin{tabular}{llllll}
\hline Model & Sum of Squares & Df & Mean Square & F & Sig. \\
& & & & & \\
\hline Regression & 48.594 & 3 & 16.198 & 59.266 & $.000^{\mathrm{a}}$ \\
Residual & 42.636 & 156 & .273 & & \\
Total & 91.230 & 159 & & & \\
\hline
\end{tabular}

a. Predictors: (Constant), Key Reasons , type of Social networking sites, Use Social Networking services b. Dependent Variable: Research Activities

Here, in above table, F-statistic values shows that all independent variables jointly determine the variation in D.V. here F-value is significant as its P-value as given in the table.

Sukkur IBA Journal of Management and Business - SIJMB | Volume 5 No. 2 July - December 2018 @ Sukkur IBA University 
Asif Mahmood et al. The Impact of the Social Networking Sites on the Research Activity of University

Table 4: Co-efficient ${ }^{\mathrm{a}}$

\begin{tabular}{|c|c|c|c|c|c|}
\hline \multirow[b]{2}{*}{ Model } & \multicolumn{2}{|c|}{ Unstandardized Coefficients } & \multicolumn{2}{|c|}{$\begin{array}{l}\text { Standardized } \\
\text { Coefficients }\end{array}$} & \multirow[b]{2}{*}{ Sig. } \\
\hline & $\mathrm{B}$ & Std. Error & Beta & $\mathrm{t}$ & \\
\hline (Constant) & .054 & .234 & & .231 & .818 \\
\hline $\begin{array}{l}\text { Use of Social Networking } \\
\text { services }\end{array}$ & .197 & .089 & .168 & 2.210 & .029 \\
\hline $\begin{array}{l}\text { type of Social networking } \\
\text { sites }\end{array}$ & .120 & .052 & .139 & 2.315 & .022 \\
\hline Key Reasons & .682 & .094 & .542 & 7.289 & .000 \\
\hline
\end{tabular}

a. Dependent Variable: Research Activities

Use of social networking sites attribute has significant positive impact on (RA). We can say that one unit change in Use of social networking sites bring change of 0.197 unit s in D.V. type of Social networking sites have positive impact on D.V but significant as $\mathrm{t}$-value is greater than 1.96 , $\mathrm{P}$-value is greater $0.02<0.05$ and beta standardized coefficient value for key reason attribute is 0.682 , which is showing a positive relation between the variables.

Histogram

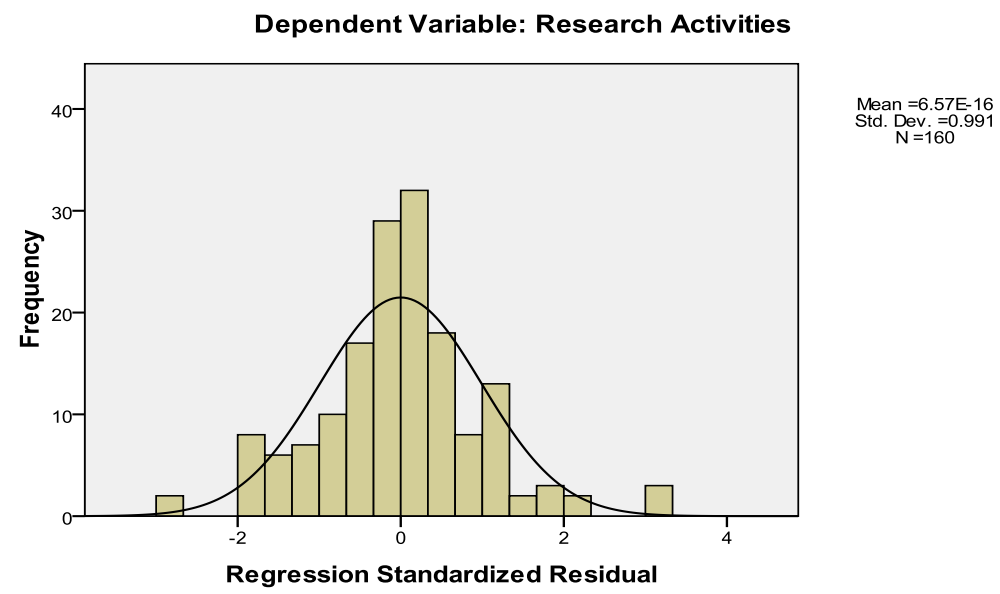

Figure 4.1 Regression Standardized Residual

Sukkur IBA Journal of Management and Business - SIJMB | Volume 5 No. 2 July - December 2018 @ Sukkur IBA University 


\section{Discussion \& Conclusion}

The students keep up no less than one record with the social networking sites,, Facebook and Whatsapp is the most mainstream person to person communication site utilized by the students as a part of Punjab University and UET, LAHORE. This backings the conclusion of Christofideset.al (2009) that Facebook is a prominent long range informal social networking site. This study demonstrates that the students know and use no less than one informal communication site. Yet at the same time, we ought to urge to keep up whatever number records as could be expected under the circumstances, as this will improve the rate of networking among different gatherings and expansion the rate of data stream for quality research. The study likewise demonstrates that the motivation behind joining a social networking site shifts among the students however the design is to stay a la mode with the group furthermore, to impart information to others. Every one of the students of PU and UET, Lahore, likewise recognized that social networking has been of benefit to them in one way or the other. Presentation to late learning, abilities and innovation in their general vicinity of specialization started things out.

\subsection{Limitations \& Contributions and Future Work}

This paper helps rehearse by giving experimental proof and explained how social advances can be appropriated effectively for bridling showing and adapting in the advanced education setting and highlighting the profits and difficulties confronted by instructors in their utilization of SNS for showing and learning. We have exhibited that the choice of social innovations and the allocation procedure are all that much focused around the inclination of the speakers. Consequently, the broad assortment of social mechanical assemblies that are open and moreover the flexibility offered by the gadgets to help diverse utilizations and applications may oblige imaginativeness and improvement from the teachers to appropriate the favored developments to sponsorship their specific needs.

There are a few ramifications of this study discoveries for different instructors and possibly, instructive fashioners in arranging, outlining and utilizing social innovations for their reasons. There are a few ramifications of this study discoveries for different instructors and conceivably, instructive planners in arranging, outlining and utilizing social advances for their reasons. Specifically, speakers could consider taking up the methodical procedure of utilizing SNS by fastidiously arranging and directing for

(a) Pre-implementation investigation of students inclination and learning styles.

(b) Leading a formal assessment of social innovations, for example, by means of SWOT examination.

(c) Planning how SNS could be utilized for classroom environment, and

(d) Evaluating the viability of SNS utilization to guarantee the showing and learning practice attains the proposed learning goals.

Sukkur IBA Journal of Management and Business - SIJMB | Volume 5 No. 2 July - December 2018 @ Sukkur IBA University 
For instructive originators, the lessons learnt from the profits and difficulties of teachers in utilizing SNS exercises to improve showing and learning ought to turn into the key pointers for them in upgrading and enhancing SNS for instructive purposes. While various social advances were not planned for educational purposes, this paper indicates they can be appropriated for appearing and learning with support of informative originators. To address the challenges, for instance, the low level of nature in using certain social innovations for appearing and learning, informational makers could enrapture instructors and their understudies in planning sessions to accommodate them the opportunity to adapt themselves with the structure plan, idiosyncrasies and comfort of the social advances. The limitation of this paper is credited to its kept association of PAKISTANI universities and the foreordained number of cases which may impact its genuine nature in various associations. Along these lines, more occurrences of appropriating social advancements for appearing and adjusting in changed colleges and in various countries would be useful to supplement the disclosures of this review. In particular, cases that show both productive and unsuccessful jobs of social developments for appearing and learning would be noteworthy to extend our seeing about the best possible use of social advances in cutting edge instruction. The Future works could be prepared towards making an "instrument compartment" that could encourage interested teachers to easily and systematically use social advancements for their appearing and learning.

\section{References:}

Brown, S. (2010). From VLEs to learning webs: the implications of Web 2.0 for learning and teaching. Interactive Learning Environments, 18(1), 1-10.

Schroeder, A., Minocha, S., \& Schneider, C. (2010). Social Software in Higher Education:

The Diversity of Applications and Their Contributions to Students' Learning Experiences. Communications of the Association for Information Systems, 26, Article 25(1), 547-564.

Ferdig, R. E. (2007). Editorial: Examining Social Software in Teacher Education. Journal of Technology and Teacher Education, 15(1), 5.

McLoughlin, C., \& Lee, J. W. L. (2008). The Three P's of Pedagogy for the Networked Society: Personalization, Participation, and Productivity. International Journal of Teaching and Learning in Higher Education 20(1), 10-27.

Wheeler, S., Yeomans, P., \& Wheeler, D. (2008). The good, the bad and the wiki: Evaluating student-generated content for collaborative learning. British Journal of Educational Technology, 39(6), 987-995.

Rifkin, W., Longnecker, N., Leach, J., Davis, L., \& Ortia, L. (2009). Motivate students by having them publish in new media: An invitation to science lecturers to share and test. Paper presented at the Motivating Science Undergraduates: Ideas and Interventions, UniServe Science Proceedings.

Sukkur IBA Journal of Management and Business - SIJMB | Volume 5 No. 2 July - December 2018 @) Sukkur IBA University 
Kennedy, G., Dalgarno, B., Bennet, S., Gray, K., Waycott, J., Judd, T., et al. (2009). Educating the Net Generation: A Handbook of Findings for Practice and Policy. Carlifornia, USA: Creative Commons.

Hemmi, A., Bayne, S., \& Land, R. (2009). The Appropriation and Repurposing of Social Technologies in Higher Education. Journal of Assisted Learning, 25(Special Issue), 19-30.

Jones, M. C., \& Twidale, M. B. (2005). What's in a name? Exploring the connections between abstraction and appropriation. International reports on socioinformatics 2(2), 43-47.

Hamid, S., Waycott, J., Chang, S. \& Kurnia, S. (2011). Appropriating Online Social Networking (OSN) activities for higher education: Two Malaysian cases. In G. Williams, P. Statham, N. Brown \& B. Cleland (Eds.), Changing Demands, Changing Directions. Proceedings ascilite Hobart 2011. (pp.526-538).

McLoughlin, C., \& Lee, J. W. L. (2008). The Three P's of Pedagogy for the Networked Society: Personalization, Participation, and Productivity. International Journal of Teaching and Learning in Higher Education 20(1), 10-27.

Tay, E., \& Allen, M. (forthcoming 2012). Designing Social networking site into university learning: technology of collaboration or collaboration for technology? Educational Media International., http://www.netcrit.net.

Jones, N., Blackey, H., Fitzgibbon, K., \& Chew, E. (2010). Get out of My Space! Computers \& Education, 54(2010), 776-782.

Kennedy,Judd, Churchward, Gray, \& Krause (2008). First Year Students' Experiences With Technology: Are They Really Digital Natives? Australasian Journal of Educational Technology (AJET 24), 24(1), 108-122.

Yampinij et al., (2012). a conceptual framework of Social networking to aid Collaborative Learning (SSCL) for improving understanding construction. Computer in human

Hamid, S. Chang, S. \& Kurnia, S. (2009). Identifying the use of online social networking in higher education. Same places, different spaces. Proceedings Ascilite Auckland 2009. Retrieved 18

Dabner, N. (2011). Design to support distance teacher education communities: A case study of a student- student ementoring initiative. Proceedings of Society for Information Technology and Teacher Education International Conference 2011. Nashville, TN: AACE 1-880094-84-3.

Mack, D. Behler, A., Roberts, B., \& Rimland. E. (2007). Reaching students with Facebook: Data and best practices. Electronic Journal of Academic and Special Librarianship, 2007, 8(2).

Ractham, P. Firpo, D. (2011), "Using Social Networking Technology to Enhance Learning in Higher Education: A Case Study Using Facebook," System Sciences (HICSS), 2011 44th Hawaii International Conference on, vol., no.pp.1-10, 4-7.

Sukkur IBA Journal of Management and Business - SIJMB | Volume 5 No. 2 July - December 2018 @ Sukkur IBA University 
Hao Jiang; MingXi Tang. (2010). "Web-Based Learning Platforms Integrating Social Networking for Design Education at High Schools in China," Computational Intelligence and Software Engineering (CiSE), International Conference, vol., no., pp.1-3, 10-12.

Gray, K., Chang, S., \& Kennedy, G. (2010). Use of social web technologies by international and domestic undergraduate students: implications for internationalizing learning and teaching in Australian universities. Technology Pedagogy and Education, 19(1), 31-46.

Griffith, S., \& Liyanage, L. (2008). An Introduction to the Potential of Social Networking Sites in education. Paper presented at the Proceedings of the Second Emerging Technologies Conference.

Oradini, F., \& Saunders, G. (2008). The Use of Social Networking By Students and Staff In Higher Education. Paper presented at the iLearning Forum, 2008, Paris.

Dale, C., \& Pymm, J. (2009). Podagogy - The iPod as a Learning Technology. Active Learning in Higher Education, 10(1), 84-96.

Andreas M. Kaplan, \& Haenlein, M. (2010). Users of the world, unite! The challenges and opportunities of Social networking site. Business Horizons, 53, 59-68.

Kane, G. C., \& Fichman, R. G. (2009). The Shoemaker's Children: Using Wikis for Information Systems Teaching, Research and Publication. MIS Quarterly, 33(1), 1-17.

Lockyer, L., \& Patterson, J. (2008). Integrating Social Networking Technologies In Education: A Case Study Of A Formal Learning Environment. Paper presented at the Eighth IEEE International Conference on Advanced Learning Technologies.

Silius, Miilumaki, Huhtamaki, Tebest, Merilainen, and Pohjolainen, (2010).Students' motivations for Social networking site enhanced studying and learning. Knowledge Management \& E-Learning: An International Journal, vol. 2, pp. 51-67.

Farwell and Waters, (2010).Exploring the use of social bookmarking technology in education: an analysis of students' experiences using a course-specific Delicious.com account. Journal of Online Learning and Teaching, vol. 6, pp. 398- 408.

Rosen and Nelson, (2008).Web 2.0: a new generation of learners and education. Computers in the Schools, vol. 25, pp. 211-225, 2008.

Hazari, North, and Moreland,(2009).Investigating pedagogical value of wiki technology. Journal of Information Systems Education, vol. 20, pp. 187-198.

Saba Mehmood (2013).The Effects of Social Networking Sites on the Academic Performance of Students in College of Applied Sciences, Nizwa, Oman. International Journal of Arts and Commerce Vol. 2 No. 1.

Nicole Ellison, (2007). The benefits of Face book "Fiends;" Social Capital and College Students' Use of Online Social Network Sites. Journal of Computer-Mediated Communication.

Sukkur IBA Journal of Management and Business - SIJMB | Volume 5 No. 2 July - December 2018 @ Sukkur IBA University 
Vaughn, Coyle (2008). Social networking: Communication revolution or evolution? Bell Labs Journal, 13-17.

Khan U (2009). Facebook students underachieve in exams. Daily Telegraph. Retrieved on July, 2013, from http://www.telegraph.co.uk/education/educationnews/5145243/Facebookstudents-underachieve-in-exams.html.

Englander, Terregrossa and Wang (2010). Educational Review, journal of education. 62(1): $85-96$.

Nalwa K, Anand AP (2003). Cyber Psychology Behavior. doi:10.1089/109493103322725441. 6(6): 653-656.

Karpinski A (2009). A description of Facebook use and academic performance among undergraduate and graduate students. Annual Meeting of the American Educational Research Association, San Diego, Calif.

Karpinski, A, \& Duberstein. (2009). A Description of Facebook Use and Academic Performance among Undergraduate and Graduate Students. San Diego, California: American Educational Research Association.

Kubey, Lavin, and Barrows (2001). Internet use and collegiate academic performance decrements: Early findings. J. Commun., 51(2): 366-382.

Wang, Chen \& Liang (2011). The Effects of Social networking site on College Students. The Alan Shawn Feinstein Graduate School. Providence: Johnson \& Wales University.

Stollak, Vandenberg, Burklund, \& Weiss (2011). Getting Social: The Impact of Social Networking Usage on grades Among College Students. ASBBS, 18(1), 859865.

Rouis, Limayem, \& Salehi-Sangari (2011). Impact of Facebook Usage on Students' Academic Achievement: Role of Self-Regulation and Trust. Journal of Research in Educational Psychology, 9(3), 961-994.

Canales, Wilbanks \& Yeoman (2009). Facebook Usage in Relation to Personality and Academic Performance. Modern Psychological Studies, Spring.

Ahmed \& Qazi (2011). A look out for academic impacts of social networking sites (SNSs): A student based perspective. African Journal of Business Management, 5(12), 5022-5031.

Hargittai, \& Hsieh (2010). Predictors and Consequences of Differentiated Practices on Soical Network Sites. Information, Communication \& Society, 13(4), 515-536.

Pasek \& Hargittai (2009, May). Facebook and academic performance: Reconciling a media sensation with data. First Monday, 14(5-4).

Dr. ThiyamSatyabati Devi\&Ms. SipiweTevera University of Swaziland (2014, Jan) (2003). Use of social networking site in the University of Swaziland by the Health Science Student: A case study. Volume 1, Number 1 January (2014), pp. 47-55

Sukkur IBA Journal of Management and Business - SIJMB | Volume 5 No. 2 July - December 2018 @ Sukkur IBA University 
McMillan \& Hwang (2002). Measures of perceived interactivity: an exploration of the role of direction and communication, user control and time in shaping perceptions of interactivity. Journal of Advertising, 31(3), 29-42.

Gallini, \& Moely (2003).Service-learning and engagement, academic challenge and retention. Michigan Journal of Community Service Learning, 5-14, fall.

So, \& Brush (2008).Students perceptions of collaborative learning, social presence and satisfaction in a blended learning environment: relationships and critical factors. Computers \& Education, 51(1), 318-336.

Chang Zhu, (2012).Student Satisfaction, Performance, and Knowledge Construction in Online Collaborative Learning.

Banks. (2006).Reflections on the use of ARS with small groups. In D. A. Banks (Ed.), Audience response systems in higher education (pp. 373-386). Hershey, PA: Information Science Publishing.

Amy Muise, M.Sc., Emily Christofides, M.Sc., and Serge Desmarais (2009). More Information than You Ever Wanted: Does Facebook Bring Out the Green-Eyed Monster of Jealousy? 